\title{
Business Performance in Young Latin American Firms
}

\author{
Hugo Kantis, Juan Federico, Pablo Angelelli, \\ and Sabrina Ibarra García
}

Aggregate data on productivity growth provides only a partial view of the Latin American reality. Indeed, one of the most salient features of business structures in the region is the presence of a high degree of heterogeneity across firms. As far as productivity is concerned, a large base of micro and small firms with low levels of productivity coexists alongside a select group of

\section{H. Kantis}

Programa de Desarrollo Emprendedor (Prodem) y Universidad Nacional de General Sarmiento, Argentina

e-mail: hkantis@gmail.com

J. Federico

Prodem (UNGS)

e-mail: juan.s.federico@gmail.com

P. Angelelli

Inter-American Development Bank

e-mail: PabloAn@IADB.ORG

S.I. García

Prodem (UNGS)

e-mail: saibarragarcia@yahoo.com.ar

(C) Inter-American Development Bank 2016 
large firms, including subsidiaries of transnational companies characterized by very high levels of productivity (Pagés 2010). As mentioned in Chap. 1, it is very important to understand the sources of this heterogeneity and to identify ways to reduce the productivity gap. One interesting dimension that deserves attention is firm age, in particular, the extent to which young firms can act as vehicles to reduce productivity gaps, since they are often considered a potential source of economic innovation, rejuvenation, and renewal. This expectation has motivated different studies in Europe and worldwide (Pellegrino et al. 2012; Schneider and Veugelers 2010; Ayyagari et al. 2011).

In Latin America, the study of young firms remains a nascent issue. Prior research has tried to understand the factors that affect the emergence of new dynamic firms by analyzing the entrepreneurial process and the characteristics of entrepreneurs (Kantis et al. 2002, 2005). Other studies used econometric methods to assess the influence of these characteristics on business growth (Federico et al. 2012; Capelleras and Kantis 2009). These studies mainly referred to the early phases of the business life cycle to demonstrate empirically the key role of entrepreneurial human capital (founders and their networks) in post-entry performance. However, they did not address the issues related to business performance that arise once firms outgrow the initial phase and move into the young firm stage.

In addition, the aforementioned studies were based on surveys conducted between 2001 and 2003. Since then, there have been many important changes in the region. For instance, most Latin American countries have experienced large economic growth periods leading to important changes not only at the economic level (e.g. new activities and new industries), but also at the social level (e.g. a larger middle class and access to education). In addition, following international trends, entrepreneurship and young growth-oriented firms have increasingly become part of the policy agenda in many Latin American countries (Kantis 2014; Kantis et al. 2012).

Interestingly, one of the unique cross-regional studies of the contribution of small and young firms to employment and job creation showed that, in Latin America, the contribution of young firms was below the median of the developing world (Ayyagari et al. 2011). Trying to shed some light on this result, a recent study affirmed that, in spite of what many people think, Latin America is characterized by a high level of entrepreneurship; however, these new firms tend to be smaller than in other regions and do not grow as much as similar firms in other regions (Lederman et al. 2014). Largely, this situation has been explained by the pre-eminence of informal micro-enterprises with low productivity levels and growth ambitions that characterize most countries in Latin America (CAF 2013). 
Others argue that among the reasons young firms grow as slowly as they do is the lack of innovation. In fact, young firms in Latin America, defined as those that have been in business for ten years or less, tended to exhibit innovation rates slightly lower than mature firms (World Bank 2014). However, the same report remarked that there was an important degree of heterogeneity in terms of the innovative profiles of young firms. In fact, by grouping young firms according to their dynamism, these authors reported that such firms-defined as those selling to foreign markets, based on new products, or having created more employment than the median in their countries-exhibited significantly higher innovation rates than older firms and other young non-dynamic firms.

In this context, there is increasing consensus about the need to change the policy emphasis from supporting small firms to supporting startups and young firms because of their potential to innovate and close the productivity and growth gaps (Lederman et al. 2014; CAF 2013). However, fulfilling these expectations depends on how sustainable and profitable young firms' growth is in the long term. Therefore, there is a need to understand the main characteristics of young Latin American firms and their growth dynamics over time. This phase of organizational development is the least explored. It is the phase during which firms, having surpassed the startup hurdles, begin to face strategic and organizational challenges that can affect business performance (Garnsey 1998; Greiner 1972; Levie and Lichtenstein 2010).

This chapter offers new empirical evidence about the performance of young firms in Latin America by focusing on four research questions. The first three questions, which are addressed using statistical analysis, are (i) What are the main characteristics of young Latin American firms and their entrepreneurs? (ii) How well do these firms perform in terms of growth and productivity? (iii) How do young firms compare with mature companies? We seek to answer the fourth question-(iv) What are the principal characteristics associated with the performance of young firms?-by estimating different econometric models using a sub-sample of the firm population. Answering these questions should provide some inputs for policymakers interested in reducing the persistent Latin American productivity gap.

\section{Conceptual Framework and Literature Review}

Davidsson et al. (2006) argued that "firm growth is a complex phenomenon. It is not unidimensional and it is hard to predict and assess. Further, it can manifest itself in various ways, and consequently it can have differential 
effects on several different levels." Firm growth has been well studied, but the results of these studies vary widely. For instance, a review of 19 studies found that high-growth firms tended to be young (Henrekson and Johansson 2010), while a US-based study found that high-growth firms tended to be more mature (Acs et al. 2008). ${ }^{1}$ Consequently, there is no unified, generally accepted theory of firm growth. Instead, different theoretical perspectives are combined in several integrated or holistic models (e.g. Baum et al. 2001; Chrisman et al. 1998; Storey 1994). These integrated approaches provide a more comprehensive view of firm growth than does an individual analysis of each variable (or set of variables) in isolation. We follow this approach to develop an integrated model of firm growth, where the following theoretical perspectives are combined: (i) entrepreneurial capabilities and firm resources, (ii) firm strategic behavior, and (iii) business regulations.

The rationale to include the characteristics of entrepreneurs is that, compared with large companies, young small and medium enterprises (SMEs) are characterized by a strong emotional connection between the owner and the firm (Chan and Foster 2001). Thus, certain characteristics of the entrepreneur strongly influence not only the type of firm that will be created, but also the way it will be managed (Bridge et al. 1998). The human capital of entrepreneurs may be seen as a unique resource (Álvarez and Busenitz 2001 ) that is formed through education and previous entrepreneurial experience (Brüderl et al. 1992). Higher education provides superior technical knowledge and contributes positively to developing individual learning capabilities to process new information and, likewise, recognize business opportunities (Shane 2000; Ucbasaran et al. 2008). Additionally, more educated entrepreneurs have the necessary skills, discipline, motivation, information, and self-confidence to attain higher growth rates in their businesses (Cooper et al. 1994). Previous working or entrepreneurial experiences also prove to be fruitful, as they provide information, knowledge, and abilities that allow the entrepreneur to efficiently solve new problems. Moreover, such experiences may contribute to the development of better technical and managerial skills, wider business networks, and access to specific, tacit knowledge about markets and customer needs (Shane 2000). Therefore, we expect the experience of the founder to have a positive effect on firm growth (e.g. Stuart and Abetti 1990; Colombo and Grilli 2005). The capabilities and characteristics of employees may also be relevant to firm performance, especially for young, growing companies.

Firm resources are relevant during the startup and young phases when firms need to achieve a threshold of scale and overcome what Stinchcombe (1965) called the "liability of newness." According to the resource-based 
view of a firm, resources are the primary driver of firm performance and greatly influence its strategy (Grant 1991). Although many resources may be identified as determinants of firm growth, one of the most studied and empirically examined has been financial capital (Cooper et al. 1994; Gilbert et al. 2006). A higher level of financial capital may allow entrepreneurs to use more aggressive growth strategies or more ambitious investment projects, which suggests there is a positive relationship between using external sources of financing (e.g. banks, governments, and venture capitalists) and business growth (Lee et al. 2001).

Additionally, financial capital may help young firms overcome their initial disadvantages and "mistakes" (Chrisman et al. 1998). Although most of the funding of young firms comes from entrepreneurs' own savings or money borrowed from relatives and friends, the amount of cash needed to accelerate growth processes usually exceeds these personal sources. Many young, growing firms rely on external sources of financing to accelerate their growth perspectives. However, smaller and younger firms tend to be at a disadvantage in securing bank credit compared to larger and older firms (see Chap. 8). Moreover, extensive research demonstrates the evolution of different sources of entrepreneurial finance throughout the life cycle of the business, for instance from friends and family during gestation to angel investors during the early stage and to venture capital for further expansion (Mason 1998; Gompers and Lerner 2004). In Latin America, these latter sources of entrepreneurial financing have recently begun to emerge but remain weakly developed (Kantis et al. 2005; Kantis 2010, 2014).

Strategic behavior is another factor that affects firm performance because it reflects the way entrepreneurs organize and assign resources to achieve business objectives. Innovation is one strategic behavior of particular importance. Innovative activities like R\&D aimed at developing new products and processes or new business models may contribute to the emergence of new firms, the establishment of a sound competitive position, and/or improvements to the levels of productivity (Acs and Audretsch 2005; Audretsch and Keilbach 2007; Quince and Whittaker 2002).

Finally, from a broad systemic perspective, the emergence of dynamic young firms also depends on the institutional setting (Kantis et al. 2005; Kantis 2014; Acs et al. 2014). Regulations form part of this setting that can directly influence the performance of young firms by either restricting or enabling growth. The institutional setting also indirectly influences performance through its effect on the business environment for young firms (i.e. access to financing, human capital, and the stock of entrepreneurs willing to start new companies). 


\section{Data And Research Methodology}

We base this study on a sample of young firms extracted from the World Bank Enterprise Surveys (WBES). We use the latest round of surveys, which were conducted in 2010. Young firms, our target group, are defined as those between four and ten years old. ${ }^{2}$ Our sample includes only those countries with information on at least 30 young firms and with no missing values in the performance indicators (sales, employment, and productivity). After applying these filters, we end up with a final sample of 1074 young firms from Argentina, Brazil, Chile, Colombia, Costa Rica, Ecuador, Guatemala, Mexico, Panama, Paraguay, Peru, and Uruguay (see tables $[6.8,6.9$, and 6.10$]$ of independent variables and performance measures in the Appendix). To measure the business performance of young firms, we consider the following variables:

- Average annual sales growth: Using Haltiwanger's specification adopted by the World Bank, we compute sales growth as the average of the differences in sales between 2007 and 2009 divided by the average sales over that period (World Bank 2013). ${ }^{3}$ We then divide this figure by the number of inter-annual periods (two) to obtain an average annual rate. The advantage of this specification is that, using average sales instead of initial sales controls for those cases where relative growth is large only because the initial base is too small, which could arguably be the case in many observations in the sample given our focus on young firms. The specific formula we use to calculate this variable is:

$$
\text { Sales Growth }=\frac{\left(\frac{(\text { Sales2009 }- \text { Sales2007 })}{(\text { Sales2009 }+ \text { Sales2007 }) / 2}\right)}{2}
$$

- Average annual employment growth: Using the same specification adopted above, we compute employment growth as the average of the differences in the number of full-time permanent workers between 2007 and 2009 divided by the average number of such workers over the same period of time. We then divide this figure by the number of inter-annual periods (two) to obtain the average annual employment growth rate.

- Labor productivity: We estimate labor productivity using the ratio of sales to the number of full-time permanent workers in 2009. 
To answer our last research question about the main factors associated with the performance of young firms, we estimate different econometric models for each of the aforementioned performance indicators. Independent variables refer to a set of dimensions associated with: (i) the capabilities of entrepreneurs and firms, (ii) the adoption of innovations, (iii) financial constraints, (iv) market strategy, (v) the regulatory framework, and (vi) firm characteristics. A complete description of these variables is provided in Table 6.7 in the Appendix. The unit of analysis is the firm and the model specification is the following:

$$
\begin{aligned}
y= & \alpha+\beta 1 E X P+\beta 2 W K F+\beta 3 T R G+\beta 4 A S S I S T+\beta 5 I N N O V+ \\
& \beta 6 F I N+\beta 7 D I V+\beta 8 R E G+\gamma A G E+\gamma 1 A G E^{2}+\theta I N S I Z E+ \\
& \theta 1 I N S I Z E^{2}+\lambda G E N+\phi L O C+\delta \text { Sector }+\delta 1 \text { Country }+\mu
\end{aligned}
$$

We estimate all of these models first using ordinary least squares (OLS) methods with robust standard errors. We limit model estimations to manufacturing firms since only these firms were asked questions about innovation practices and human resource capabilities. In addition, we exclude Brazilian firms from our estimations since the survey did not include data about innovation or information on technical assistance and human resources. ${ }^{4}$ The number of observations in the models declines to 444 firms as a result of these restrictions. ${ }^{5}$

We have a few caveats on the limitations of the data that could affect our estimation results. First, the sample includes only surviving firms. Survival and attrition bias is a question largely discussed in the literature on firm growth (e.g. Nightingale and Coad 2013). This bias principally affects the representativeness of our sample since it includes only a subset of young survivor firms. Hence, some caution should be taken when trying to generalize the results of this study for the whole population. ${ }^{6}$ Also, our sample includes outliers and variables with a huge dispersion due to extreme values, ${ }^{7}$ which is expected given the heterogeneous nature of the firm population under study. To deal with this, we report the median instead of the mean as a summary measure.

\section{Young Latin American Firms and Their Entrepreneurs: A Portrait Based on Descriptive Statistics}

Almost one in five Latin American firms is young, meaning it is between four and ten years old. ${ }^{8}$ The majority of young firms in the region are between eight and ten years old. Young firms in Chile, Ecuador, and 
Panama tend to be older than the rest of the sample, while those in Uruguay and Costa Rica tend to be younger. Interestingly, in several countries, especially Argentina, Chile, and Peru, young firms tend to have a larger presence in knowledge-based sectors (i.e. technology services and engineering-intensive manufacturing) than the more mature companies, demonstrating a trend toward the diversification of the regional industrial structure. ${ }^{9}$ Most of the entrepreneurs are male, although $40 \%$ of the young firms are either managed by a woman or have a woman among their founders. ${ }^{10}$

Looking at prior experience, the entrepreneurs in young firms tended to work as employees before starting their companies ( $75 \%)$; only one-third held managerial positions prior to working at the current firm. This finding is more frequent in Argentina (44\%), Chile (42\%), Guatemala (40\%), and Paraguay (47\%). ${ }^{11}$ The Argentinean, Chilean, and Colombian entrepreneurs have the most experience in a similar industry (at least 20 years). Previous industry experience may positively influence business growth by allowing the entrepreneur to exploit competitive advantages derived from tacit knowledge, mainly by knowing both how and who. Entrepreneurs who were previously unemployed or that started their own company because of a lack of better job opportunities represent a limited proportion of the sample $(3 \%)$. Of note, informal enterprises, where necessity entrepreneurship tends to dominate, are not included in the WBES.

In terms of firm size, half of the young Latin American firms in the sample employ between 10 and 49 full-time workers. ${ }^{12}$ In other words, firms tend to be small, with a median number of full-time workers of around 18; however, there is significant dispersion across firms, with manufacturing firms (20 full-time workers) tending to be larger than services firms (17). These figures hide an important heterogeneity among countries. In Peru (seven full-time workers) and Panama (eight), the median sizes of young firms tend to be smaller; whereas in Chile (35) and Costa Rica (47), firms tend to be larger, though still smaller than mature firms. ${ }^{13}$

In general, most young firms tend to focus their sales in domestic markets. At the regional level, $84 \%$ do not export (compared to $75 \%$ of mature companies) and direct exports account for less than $5 \%$ of sales. Only in Costa Rica, Argentina, and Peru is there a relevant group of young active exporters (i.e. exporting $20 \%$ or more of their sales). ${ }^{14}$ Young international new ventures or "born globals," as referred to in the literature, are not a generalized phenomenon in the region. ${ }^{15}$ 
Data on innovation-related activities indicate that almost $43 \%$ of the young firms in Latin America performed R\&D activities between 2007 and 2009, in line with mature firms. Moreover, most of the ones we study introduced new products and/or processes during this period. ${ }^{16}$ On the one hand, Argentina, Paraguay, and Uruguay had more young firms introducing new products. On the other hand, process innovations were more frequent among young firms in Chile, Colombia, and Peru. These findings align with the study presented in Chap. 2, which found that most firms in the region are actively introducing product and/or process innovations. While both young and mature firms innovate at similar rates, new products introduced by young firms constitute a larger proportion of sales compared to mature firms. New products account for at least $25 \%$ of sales in young firms compared to roughly $33 \%$ of sales in mature firms.

\section{The Growth of Young Latin American Firms}

Young Latin American firms usually begin operations as micro-enterprises. More than $40 \%$ have no more than five employees during the initial startup phase. ${ }^{17}$ Young firms in certain countries, like Chile and Argentina, tend to start bigger than those in other countries (their median size is twice that for the region of six employees). Once in the market, these young firms do not just survive, but grow enough to become part of the SME segment. In fact, the median size in 2007, when these firms were about five years old, was 15 full-time workers-three times the initial size. ${ }^{18}$ However, this initial growth tends to slow down in subsequent years; the increase in median firm size between 2007 and 2009 was just $20 \%$. Interestingly, this performance cannot be attributed, at least predominantly, to the international crisis since the effect in most Latin American countries was small (World Bank 2010).

In addition, young firms, on the whole, perform better than mature companies. For instance, young firms in 9 out of 12 Latin American countries saw their sales growth outperform that of mature firms (5 vs $1.3 \%$, respectively, using median values). ${ }^{19}$

Even in a context of lower dynamism, $28 \%$ of young Latin American firms grew in size (employment) at an annual average rate of $20 \%$ during the period surveyed..$^{20}$ In other words, a large number of young firms in our sample could be identified as high growth performers, despite the general finding of low firm-level growth. ${ }^{21}$ 
To capture the heterogeneity of the growth profiles of young firms, we propose a taxonomy that takes into account the different growth rates of past years and the final scale achieved. For the different thresholds for firm growth, we adopt the definitions of the OECD and the Global Entrepreneurship Monitor for moderate (annual average growth of $10 \%$ ) and high growth $(20 \%)$. The scale is calculated using a widely recognized size threshold based on employment. We define a micro-enterprise as a firm that has fewer than ten employees, while an SME has ten or more. By combining both variables (growth and final scale), we arrive at a taxonomy based on five categories (see Table 6.1 and Fig. 6.1).

Table 6.1 Taxonomy of young firms

\begin{tabular}{|c|c|c|c|c|}
\hline & & \multicolumn{3}{|c|}{ Average sales growth rate (2007-2009) } \\
\hline & & $\begin{array}{l}\text { Low growth } \\
\text { (10\% or } \\
\text { below) }\end{array}$ & $\begin{array}{l}\text { Moderate growth } \\
(11 \% \geq 19 \%)\end{array}$ & $\begin{array}{l}\text { High growth }(20 \% \\
\text { or more) }\end{array}$ \\
\hline \multirow[t]{2}{*}{$\begin{array}{l}\text { Size (Employees } \\
\text { in 2009) }\end{array}$} & $\begin{array}{l}\text { Micro (1-9 } \\
\text { employees) }\end{array}$ & \multicolumn{2}{|c|}{ Low-growth micro-enterprises } & $\begin{array}{l}\text { Micro-enterprises } \\
\text { in transition }\end{array}$ \\
\hline & $\begin{array}{l}\text { SME (10+ } \\
\text { employees) }\end{array}$ & $\begin{array}{l}\text { Low-growth } \\
\text { SMEs }\end{array}$ & $\begin{array}{l}\text { Moderate- } \\
\text { growth SMEs }\end{array}$ & $\begin{array}{l}\text { High-growth } \\
\text { SMEs }\end{array}$ \\
\hline
\end{tabular}

Source: Authors' elaboration

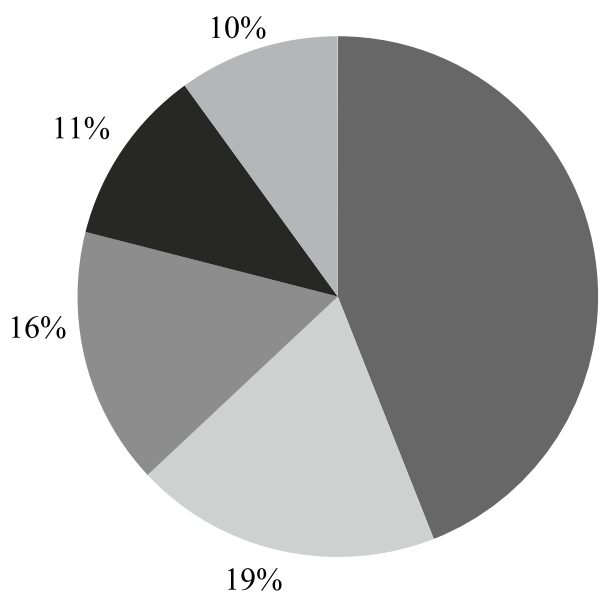

$44 \%$

- Low-growth SMEs

High-growth SMEs

Low-growth micro-enterprises

- Moderate-growth SMEs

Micro-enterprises in transition

Fig. 6.1 Composition of the sample according to the taxonomy of the growth and scale of young firms

Source: Authors' elaboration based on WBES data 
Using this taxonomy, Fig. 6.1 shows that low-growth SMEs make up the largest group (44\%) within the subset of young firms. These are the firms that grew enough to become an SME, but stagnated in subsequent years. High-growth SMEs are the second largest group (19\%), followed by moderate-growth SMEs (11\%). Two distinct groups arise from the microenterprises: the first comprises micro-firms with low to negative growth rates ( $16 \%$ of firms), and the second those micro-enterprises experiencing high enough growth to be transitioning into the world of SMEs $(10 \%)$. Overall, if we only consider those firms that experienced moderate to high growth rates during the 2007-2009 period (i.e. micro-enterprises in transition, moderate-growth SMEs, and high-growth SMEs), we see that growing firms represent $40 \%$ of the total sample of young firms.

One interesting feature of the high-growth SME segment is its important contribution to the sophistication of the regional business structure. For instance, these firms $(29 \%)$ tend to be more concentrated in knowledge-intensive sectors, such as engineering-intensive manufacturing or technological services, than the rest of the young firms $(21 \%)$ or the mature firms $(21 \%){ }^{22}$ To a lesser extent, the same is the case for microenterprises in transition ( $27 \%$ are in knowledge-intensive sectors), supporting the idea that they have potential to enlarge the base of growing and innovative SMEs.

\section{The Productivity of Young Latin American Firms}

In terms of labor productivity, the results of our sample show that young firms' productivity levels are lower than those of mature firms. To calculate the productivity gap, we estimate the labor productivity for each firm using the logarithm of sales per employee in the previous fiscal year, with sales expressed in constant 2009 US dollars. Then, we compute the medians for these values and compare young and mature firms. We use the median instead of the mean because this measure is less sensitive to outliers and extreme values. At the regional level and considering all the sectors, the productivity gap between young and mature firms in 2009 was about $21 \%$ (Table 6.2). Three years earlier this difference was $27 \%$, thus the gap was shrinking. By sector, the results are mixed. For services and manufacturing firms, the gap narrowed, while for commercial firms, the gap widened.

Overall, the progress made in reducing the productivity gap can be attributed to improving productivity in young firms, especially in the services 
Table 6.2 Productivity gap between young and mature firms by sector (median values)

\begin{tabular}{llr}
\hline & Productivity gap (mature firms $=100)$ \\
\hline Sector & 2007 & 2009 \\
\hline Manufacturing & 73.7 & 79.4 \\
Commerce & 84.4 & 73.9 \\
Services & 70.3 & 81.1 \\
\hline Total & 72.8 & 79.2 \\
\hline
\end{tabular}

Source: Authors' elaboration based on WBES data

Table 6.3 Productivity growth between 2007 and 2009 by age and sector (median values)

\begin{tabular}{lll}
\hline Sector & $\begin{array}{l}\text { Productivity growth: } \\
\text { young firms (\%) }\end{array}$ & $\begin{array}{l}\text { Productivity growth: } \\
\text { mature firms (\%) }\end{array}$ \\
\hline Manufacturing & 1.4 & -2.3 \\
Commerce & -7.7 & -1.1 \\
Services & 4.9 & -2.3 \\
\hline Total & 2.1 & $-\mathbf{2 . 1}$ \\
\hline
\end{tabular}

Source: Authors' elaboration based on WBES data

sector. At the same time, mature firms experienced some setbacks in their productivity levels, which contributed to closing the gap (Table 6.3).

However, as mentioned, young firms are not a homogeneous group and comparing productivity levels according to the taxonomy of young firms reveals interesting results. For example, the levels of productivity among growing SMEs (moderate and high growth) are similar to those observed among mature firms. This situation is chiefly driven by the manufacturing sector, where young growing SMEs outperform mature firms. In addition, high-growth SMEs and micro-enterprises in transition show the biggest increases in productivity. Trends among moderate-growth SMEs are mixed: positive in commerce and services but negative in manufacturing (Table 6.4).

In sum, there is widespread heterogeneity among young firms. Between 2007 and 2009, their initial growth slowed. Despite this, the taxonomy proposed in this chapter shows that an important segment of young SMEs has continued growing and contributed to closing the productivity gap with mature firms. At the same time, a promising segment of rapidly growing micro-enterprises has been identified. The next section explores in depth the main factors associated with young manufacturing firms' growth and productivity. 
BUSINESS PERFORMANCE IN YOUNG LATIN AMERICAN FIRMS 179

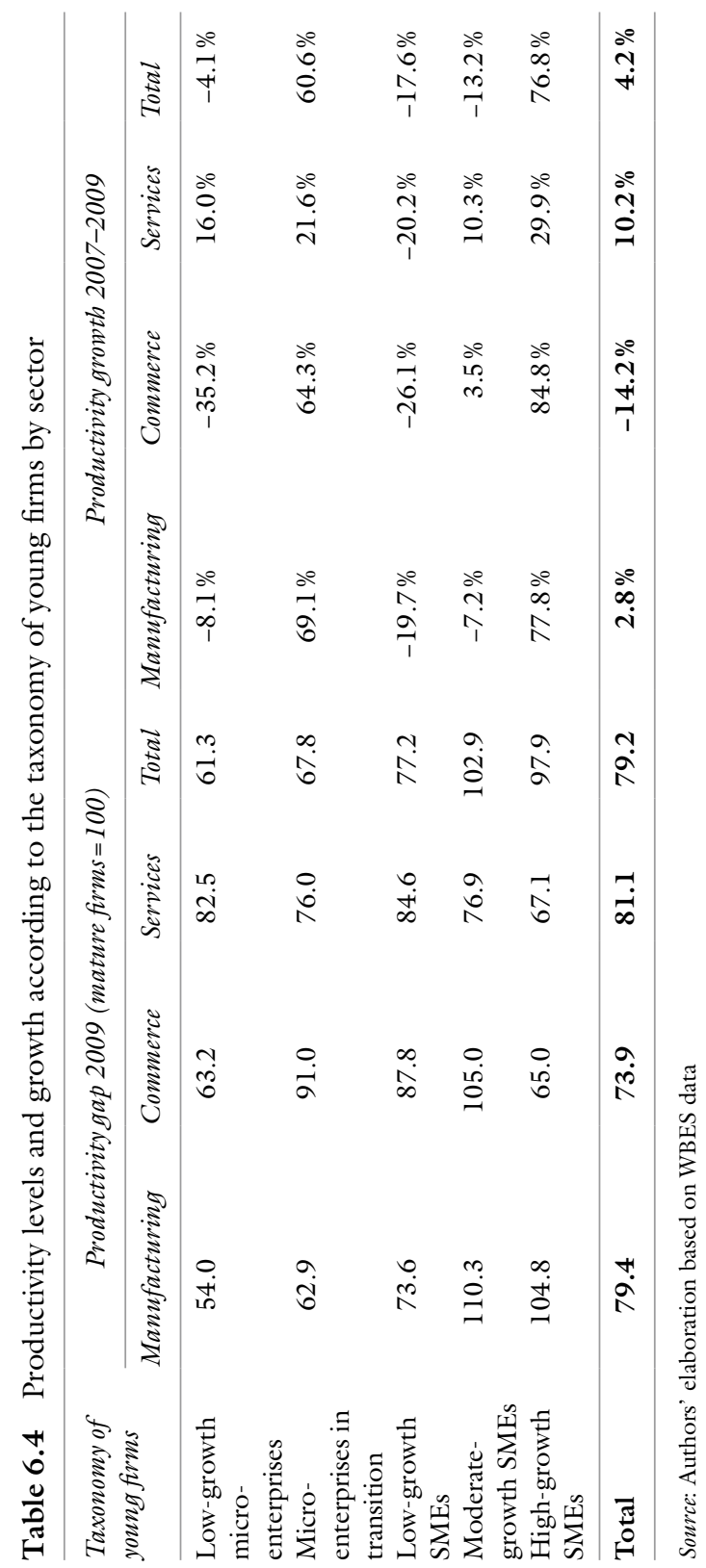




\section{The Performance of Young Manufacturing Firms: Estimation Results ${ }^{23}$}

In this section, we use OLS regression techniques to identify the main factors associated with the performance of young firms. We estimate four models using performance measures for labor productivity, sales growth, and employment growth as the dependent variables. We estimate additional models to check robustness.

\section{Labor Productivity}

Table 6.5 presents the OLS regression results for the two specifications using the logarithm of labor productivity levels as the dependent variable. Model 1 includes the main firm characteristics described earlier. Model 2 slightly adapts the first model by including a variable that captures the potential effect of firm dynamism on productivity levels by adding a dummy variable equal to one for high-growth firms and zero otherwise. ${ }^{24}$

Model 1 shows a positive and statistically significant association between workforce training and labor productivity for the sample of young manufacturing firms under study. There is a similar statistically significant relationship for hiring technical assistance (0.304). As we suggested earlier, these results propose that human capital variables (internal and external) can play an important role in boosting the productivity levels of young firms, which may help improve their competitive position in the market. In fact, as Model 2 shows, there is a positive and statistically significant relationship between the high growth status of young manufacturing firms and productivity levels. That is, productivity levels of high growth firms are, on average, 32 percentage points higher than their non-high growth counterparts.

Unsurprisingly, financial constraints are negatively associated with labor productivity in both models. The models show that young manufacturing firms that are either rationed or discouraged (financial constraint variable), on average, have labor productivity 25 percentage points lower, holding all else equal. However, the direction of causality could be the reverse, with less productive firms facing more difficulties accessing external resources.

Other variables, such as innovating and adopting diversification strategies, do not seem to be statistically associated with productivity. To some extent, this could be due to non-contemporaneous effects. ${ }^{25}$ Finally, initial size has a slight positive effect on labor productivity, meaning firms that 
Table 6.5 Regression outputs: labor productivity levels (in logs)

\begin{tabular}{|c|c|c|}
\hline & Model 1 & Model 2 \\
\hline Industry experience & $\begin{array}{l}0.0013 \\
(0.0048)\end{array}$ & $\begin{array}{l}0.0009 \\
(0.0047)\end{array}$ \\
\hline Workforce capabilities & $\begin{array}{l}0.0052^{*} \\
(0.0029)\end{array}$ & $\begin{array}{l}0.0053^{*} \\
(0.0029)\end{array}$ \\
\hline Workforce training & $\begin{array}{l}0.3302 * * * \\
(0.1039)\end{array}$ & $\begin{array}{l}0.3223^{* * *} \\
(0.1014)\end{array}$ \\
\hline Technical assistance & $\begin{array}{l}0.3037^{* * *} \\
(0.1036)\end{array}$ & $\begin{array}{l}0.2734^{* * *} \\
(0.103)\end{array}$ \\
\hline Innovation & $\begin{array}{l}0.105 \\
(0.1022)\end{array}$ & $\begin{array}{l}0.103 \\
(0.1019)\end{array}$ \\
\hline Financial constraint & $\begin{array}{l}-0.2480 \text { ** } \\
(0.0966)\end{array}$ & $\begin{array}{l}-0.2278^{* *} \\
(0.0974)\end{array}$ \\
\hline Diversification & $\begin{array}{l}-0.001 \\
(0.0017)\end{array}$ & $\begin{array}{l}-0.0011 \\
(0.0016)\end{array}$ \\
\hline Regulations & $\begin{array}{l}0.0237 \\
(0.0511)\end{array}$ & $\begin{array}{l}0.0217 \\
(0.0507)\end{array}$ \\
\hline Firm age & $\begin{array}{l}-0.0411 \\
(0.0324)\end{array}$ & $\begin{array}{l}-0.0343 \\
(0.0323)\end{array}$ \\
\hline Firm age squared & $\begin{array}{l}0.0074 \\
(0.0126)\end{array}$ & $\begin{array}{l}0.0084 \\
(0.0126)\end{array}$ \\
\hline Initial size & $\begin{array}{l}0.0027^{* * *} \\
(0.001)\end{array}$ & $\begin{array}{l}0.0031 * * * \\
(0.001)\end{array}$ \\
\hline Initial size squared & $\begin{array}{l}-0.0000^{* *} \\
(0.0000)\end{array}$ & $\begin{array}{l}-0.0000^{* *} \\
(0.0000)\end{array}$ \\
\hline Gender & $\begin{array}{l}-0.2367 * * * \\
(0.0892)\end{array}$ & $\begin{array}{l}-0.2207 * * \\
(0.0884)\end{array}$ \\
\hline Location & $\begin{array}{l}0.0407 \\
(0.1568)\end{array}$ & $\begin{array}{l}0.0418 \\
(0.1562)\end{array}$ \\
\hline High growth $(=1)$ & n.a. & $\begin{array}{l}0.3160 \text { ** } \\
(0.1278)\end{array}$ \\
\hline Constant & $\begin{array}{l}10.1816^{* * *} \\
(0.267)\end{array}$ & $\begin{array}{l}10.1492 * * * \\
(0.267)\end{array}$ \\
\hline $\mathrm{N}$ & 444 & 444 \\
\hline F-test & $13.05^{* * *}$ & $12.36 * * *$ \\
\hline $\mathrm{R}^{2}$ & 0.3349 & 0.3463 \\
\hline
\end{tabular}

Source: Authors' elaboration based on WBES data

Notes: * Coefficient is statistically significant at the $10 \%$ level, ** at the $5 \%$ level, *** at the $1 \%$ level; no asterisk means the coefficient is not different from zero with statistical significance. Robust standard errors are reported in parenthesis. Industry and country dummies are included but they are not reported here for the sake of simplicity. n.a. = not applicable 
started out larger had higher productivity levels, although the magnitude of the effect is quite small. This finding may be due to minimum economies of scales.

\section{Sales and Employment Growth}

Previous studies in Latin America generally found a positive relationship between firm performance and entrepreneurial capabilities (Kantis et al. 2005; Federico et al. 2012). However, as discussed below, our estimations cannot confirm these results.

In the first model, the dependent variable is sales growth. The results of the OLS estimation show that, on the one hand, entrepreneurs' industryspecific experience has a slight positive association with sales growth; however, it is only significant at the $10 \%$ level and the magnitude is quite small. On the other hand, hiring technical assistance for quality control and/or certification has a positive relationship with sales growth and is statistically significant at the $1 \%$ level. Technical assistance is associated with a 9 percentage point increase in sales growth, all else being equal. In addition, the perception that regulations are an obstacle (e.g. taxation, trade and labor norms, and licenses and permits) has a negative effect on sales growth at a $5 \%$ significance level, although no such effect was found for employment growth. This result shows the negative influence that the regulatory framework may have on sales growth, although we note that obstacles are based on the subjective opinions of survey respondents. ${ }^{26}$ Finally, neither workforce capabilities nor training were significant in the sales growth model.

The second model looks at employment growth. Those variables associated with the capabilities of entrepreneurs and firms (i.e. entrepreneurs' industry experience, workforce capabilities, and training) are all positively related with growth, but none are statistically significant. In turn, the results show that employment growth is negatively associated with firms that are credit constrained or discouraged, which may suggest the importance of access to external financing to expand the workforce. Financially constrained young manufacturing firms are associated with a larger decrease in employment growth than non-financially constrained firms (of about 6 percentage points), all else being equal. Young firms may need additional sources of financing to expand employment. Finally, 
we find a negative and highly statistically significant relationship between initial size and employment growth. This result, also observed in the sales growth model, suggests that young firms that begin operations with a smaller initial size tend to grow at a higher rate than those whose initial size was larger. In addition, we find evidence of a non-linear influence of initial size on growth. This could mean that smaller young firms need to grow at a greater rate in order to overcome their initial size disadvantages and to increase their chances of survival. However, the magnitude of these coefficients is small and they should be interpreted accordingly.

In sum, both the sales and employment growth models demonstrate low predictive power $\left(\mathrm{R}^{2}\right)$. However, a few significant findings emerge. One interesting result is that sales and employment growth are not affected by the same constraints. ${ }^{27}$ This result is not necessarily obvious for policymakers who tend to associate firm growth with job creation. For example, while technical assistance is found to be statistically associated with sales growth, the same relationship is not found for employment growth; regulations are found to have a negative and statistically significant effect on sales growth, but not on employment growth. Instead, in the employment growth model, access to external financing is the obstacle that has a negative and statistically significant effect on employment growth. One commonality between the two models is the negative association between initial firm size and growth. However, the low explanatory power of both models suggests that there might be other important variables associated with growth of young firms that are not accounted for here. Some of these variables could include entrepreneurial team characteristics, strategy implementation, entrepreneurial orientation, or the role of networks, which could not be included due to data limitations (Table 6.6).

\section{Robustness Checks}

We perform several sensitivity tests to examine further the empirical robustness of our results. We conduct these checks to observe whether a change in the key variables produces measurably different results (i.e. due to measurement error). ${ }^{28}$ In the first test, we substitute firm productivity growth for the dependent variable firm productivity level. Using firm productivity growth, the results are qualitatively similar to those in the above models. Simple regressions show a positive association of both techni- 
184 H. KANTIS ET AL.

Table 6.6 Regression results: sales and employment growth

\begin{tabular}{|c|c|c|}
\hline Dependent variable & Sales growth & Employment growth \\
\hline Industry experience & $\begin{array}{l}0.0024^{*} \\
(0.0013)\end{array}$ & $\begin{array}{l}0.0002 \\
(0.0010)\end{array}$ \\
\hline Workforce capabilities & $\begin{array}{l}0.0006 \\
(0.0008)\end{array}$ & $\begin{array}{l}0.0007 \\
(0.0007)\end{array}$ \\
\hline Workforce training & $\begin{array}{l}0.0112 \\
(0.0327)\end{array}$ & $\begin{array}{l}0.0137 \\
(0.0236)\end{array}$ \\
\hline Technical assistance & $\begin{array}{l}0.0905^{* * *} \\
(0.0319)\end{array}$ & $\begin{array}{l}0.0263 \\
(0.0257)\end{array}$ \\
\hline Innovation & $\begin{array}{l}0.0002 \\
(0.0308)\end{array}$ & $\begin{array}{l}-0.024 \\
(0.0232)\end{array}$ \\
\hline Financial constraint & $\begin{array}{l}-0.038 \\
(0.0286)\end{array}$ & $\begin{array}{l}-0.0558^{* *} \\
(0.0237)\end{array}$ \\
\hline Diversification & $\begin{array}{l}-0.0005 \\
(0.0005)\end{array}$ & $\begin{array}{l}0.0001 \\
(0.0004)\end{array}$ \\
\hline Regulations & $\begin{array}{l}-0.0304^{* *} \\
(0.0151)\end{array}$ & $\begin{array}{l}-0.0067 \\
(0.0129)\end{array}$ \\
\hline Firm age & $\begin{array}{l}-0.0141 \\
(0.0091)\end{array}$ & $\begin{array}{l}-0.0112 \\
(0.0075)\end{array}$ \\
\hline Firm age squared & $\begin{array}{l}0.0069 * \\
(0.0039)\end{array}$ & $\begin{array}{l}0.0021 \\
(0.003)\end{array}$ \\
\hline Initial size & $\begin{array}{l}-0.0009 * * * \\
(0.0002)\end{array}$ & $\begin{array}{l}-0.0008 * * * \\
(0.0002)\end{array}$ \\
\hline Initial size squared & $\begin{array}{l}0.0000 * * * \\
(0.0000)\end{array}$ & $\begin{array}{l}0.0000 * * * \\
(0.0000)\end{array}$ \\
\hline Gender & $\begin{array}{l}-0.0702 * * * \\
(0.0282)\end{array}$ & $\begin{array}{l}0.0116 \\
(0.0233)\end{array}$ \\
\hline Location & $\begin{array}{l}-0.0021 \\
(0.0371)\end{array}$ & $\begin{array}{l}0.0245 \\
(0.0318)\end{array}$ \\
\hline Constant & $\begin{array}{l}0.082 \\
(0.0667)\end{array}$ & $\begin{array}{l}0.0633 \\
(0.0531)\end{array}$ \\
\hline $\mathrm{N}$ & 444 & 444 \\
\hline F-test & $2.56 * * *$ & $1.96^{* * *}$ \\
\hline $\mathrm{R}^{2}$ & 0.1317 & 0.0810 \\
\hline
\end{tabular}

Source: Authors' elaboration based on WBES data

Notes: * Coefficient is statistically significant at the $10 \%$ level, ** at the $5 \%$ level, *** at the $1 \%$ level; no asterisk means the coefficient is not different from zero with statistical significance. Robust standard errors are reported in parenthesis. Industry and country dummies are included but they are not reported here for the sake of simplicity 
cal assistance and industry experience on firm productivity, although the association is only statistically significant for technical assistance at the $5 \%$ level. This is consistent with the positive relationships found in the above four models. We also do a second check with firm profitability. We find similar positive relationships between technical assistance and industry experience, and firm profitability, although neither association was significant. In addition, innovation is positively associated with firm profitability at the $10 \%$ level, whereby a firm's innovation increases firm profitability by 6.9 percentage points, all else being equal. This is the only model that shows innovation significantly affecting firm performance (albeit at a low level). On the whole, these results demonstrate that the direction of the main independent variables do not change when we use different measures of firm performance. In other words, the results are not sensitive to only one measure of firm performance.

\section{Conclusions and Policy Implications}

Young firms are receiving an increasing amount of attention worldwide. Their potential economic contribution has transformed them into relevant players whose importance for productivity growth should not be ignored. In Latin America, any strategy aimed at closing the productivity gap should consider young firms as part of the growing number of competitive SMEs. The key question is to what extent these young firms can contribute to reducing this gap.

To shed some light on their characteristics and performance, we analyzed a sample of young firms from selected Latin American countries. The findings demonstrated the heterogeneous nature of young firms. In particular, we observed that high- and moderate-growth SMEs, especially in the manufacturing sector, are more productive than mature firms, which could help close the productivity gap. Micro-enterprises in transition showed important increases in productivity, raising positive expectations for their potential in the future. We also found that most of the young firms we sampled managed to survive and grow enough within a five-year period to become part of the SME sector. This first stage of important growth tended to slow down during the last three years, although an 
important group of them continued to grow. In this general context of low growth rates, young firms tended to outperform more mature firms.

These results highlight the need to avoid generic and uniform strategies that assume a one-type-fits-all scenario. The key challenges in reducing the productivity gap and fostering a more innovative business sector require renewed focus on young firms. However, not all young firms are equally equipped to contribute to improved performance in the Latin American business sector. Instead, a more selective approach is needed. The results of this study tend to discourage those very restrictive niche policy targets (i.e. policies oriented toward fast-growing "gazelles"). The taxonomy of young firms developed in this chapter suggests adopting a broader strategic vision aimed at enlarging the competitive SME sector by segmenting the programs, setting objectives, and implementing instruments adjusted for each segment. In particular, high-growth young SMEs should be supported without diverting attention to moderate-growth SMEs and micro-enterprises in transition. This could be a promising route for both developing young firms in the region and for closing the productivity gap.

Conceptually, growth and productivity constitute pillars of the longterm competitiveness of young firms. In this chapter, we used econometric models to identify the main factors associated with the sales and employment growth of young firms, and productivity levels. According to the results of the regressions, one way to foster the growth of young firms is to support their access to and development of know how and know who. Indeed our research found that workforce training and technical assistance were positively associated with productivity in young manufacturing firms. Mentoring programs and networking activities that make access to know how and know who easier, and quality management technical assistance, are promising ways to achieve these goals. ${ }^{29}$ The models also showed that those firms that started at a smaller scale tended to grow at higher rates. This result may suggest the need to grow in order to overcome the disadvantages associated with their limited scale during the initial stages of the business lifecycle. Furthermore, considering our sample only includes surviving firms, this implication is even more important. Entrepreneurship policies should focus not only on startups but also on young firms' needs 
to scale up in order to face the specific challenges present at each stage of development.

Another interesting result of this study was the importance of removing the financial and regulatory constraints facing young firms. In particular, we found that financial constraints hindered productivity and employment growth. This demonstrated that venture capital initiatives alone may not be enough for a young firm to grow and that other financial products are needed that provide working capital at a lower cost than equity. Nurturing the entire finance curve (i.e. covering all stages of firm development) should be a key policy objective. Additionally, we found that regulations negatively affect sales growth. The perceptions of tax rates and tax regulations as obstacles seemed to provide disincentives for young firm performance. There is a clear need to review the regulations and taxes that inhibit creating and developing growth-oriented SMEs. These policies should be rethought to set the right incentives for dynamic entrepreneurship.

Even with these findings, our models explained a relatively low percentage of the variation in firm performance, setting the stage for further research in this area. For example, the introduction of new processes or products did not have a significant impact on the performance of young firms. This brings to light the need to give greater attention to the effectiveness of innovation efforts by such firms. For instance, the issue could be rooted in a lack of capabilities to manage the implementation of such projects. In this case, training programs on innovation management, innovation clubs that share best practices, or partial subsidies of innovation certified consultants could be part of a future agenda. Therefore, one possible way to support innovation would be to subsidize part of the cost of highly qualified human resources engaged in innovative projects led by young firms. ${ }^{30}$

Overall, this chapter offers a first glimpse into young business performance. We derived clear policy implications from the results despite some data limitations. Further research is needed to deepen the understanding of the dynamics of young business performance and the contribution of young firms to economic development in the region. 


\section{Appendix}

Table 6.7 Definition of independent variables

\begin{tabular}{|c|c|c|c|}
\hline Dimension & Variable & Definition & Type \\
\hline \multirow[t]{4}{*}{$\begin{array}{l}\text { Capabilities of } \\
\text { entrepreneurs and } \\
\text { firms }\end{array}$} & $\begin{array}{l}\text { Entrepreneurs' } \\
\text { industry experience }\end{array}$ & $\begin{array}{l}\text { Years of previous experience } \\
\text { in the same industry of the } \\
\text { top management }\end{array}$ & Continuous \\
\hline & $\begin{array}{l}\text { Workforce } \\
\text { capabilities }\end{array}$ & $\begin{array}{l}\text { Proportion of the workforce } \\
\text { with at least a Bachelor's degree }\end{array}$ & Continuous \\
\hline & Workforce training & $\begin{array}{l}\text { Dummy variable that equals } \\
1 \text { if the firm has implemented } \\
\text { some training activities }\end{array}$ & Binary \\
\hline & Technical assistance & $\begin{array}{l}\text { Dummy variable that equals } \\
1 \text { if the firm has hired some type } \\
\text { of external technical services* }\end{array}$ & Binary \\
\hline Innovation & $\begin{array}{l}\text { Product and process } \\
\text { innovation }\end{array}$ & $\begin{array}{l}\text { Dummy variable that } \\
\text { assumes value } 1 \text { if the firm } \\
\text { has introduced some product } \\
\text { and/or process innovation over } \\
\text { the last three years }\end{array}$ & Binary \\
\hline Financial resources & Financial constraints & $\begin{array}{l}\text { A dummy variable that assumes } \\
\text { value } 1 \text { in the case of firms that } \\
\text { were rationed from banks or } \\
\text { were discouraged from applying } \\
\text { to a line of credit }\end{array}$ & Binary \\
\hline Market strategy & Diversification & $\begin{array}{l}\text { The mathematical complement } \\
\text { of the percentage of sales } \\
\text { corresponding to the main product }\end{array}$ & Continuous \\
\hline
\end{tabular}


Table 6.7 (continued)

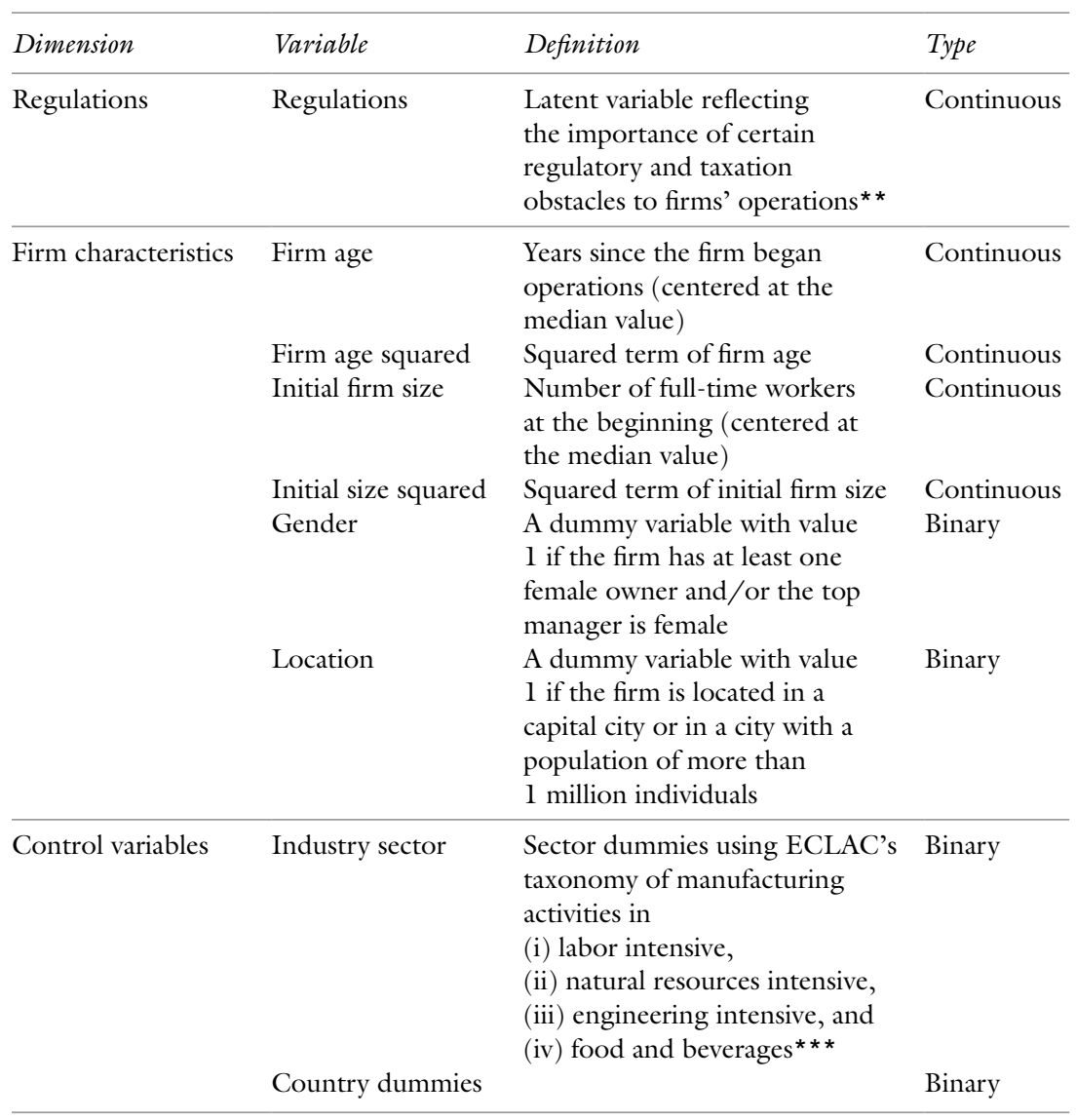

Notes: *We tested different types or areas of technical assistance and chose to report only the one corresponding to quality certification and quality management. ** To build the "regulations" variable, we conducted a Principal Components Factor Analysis on different interrelated scale variables. We asked the respondents to what extent (from 1 to 5 ) each of the following issues were an obstacle for their operations: (i) customs and trade regulations, (ii) tax rates, (iii) tax administration, (iv) labor regulations, (v) licenses and permits. The Cronbach Alpha for this construct was 0.751. *** We also used the OECD's taxonomy of technological level, and the results were the same as using ECLAC's taxonomy 


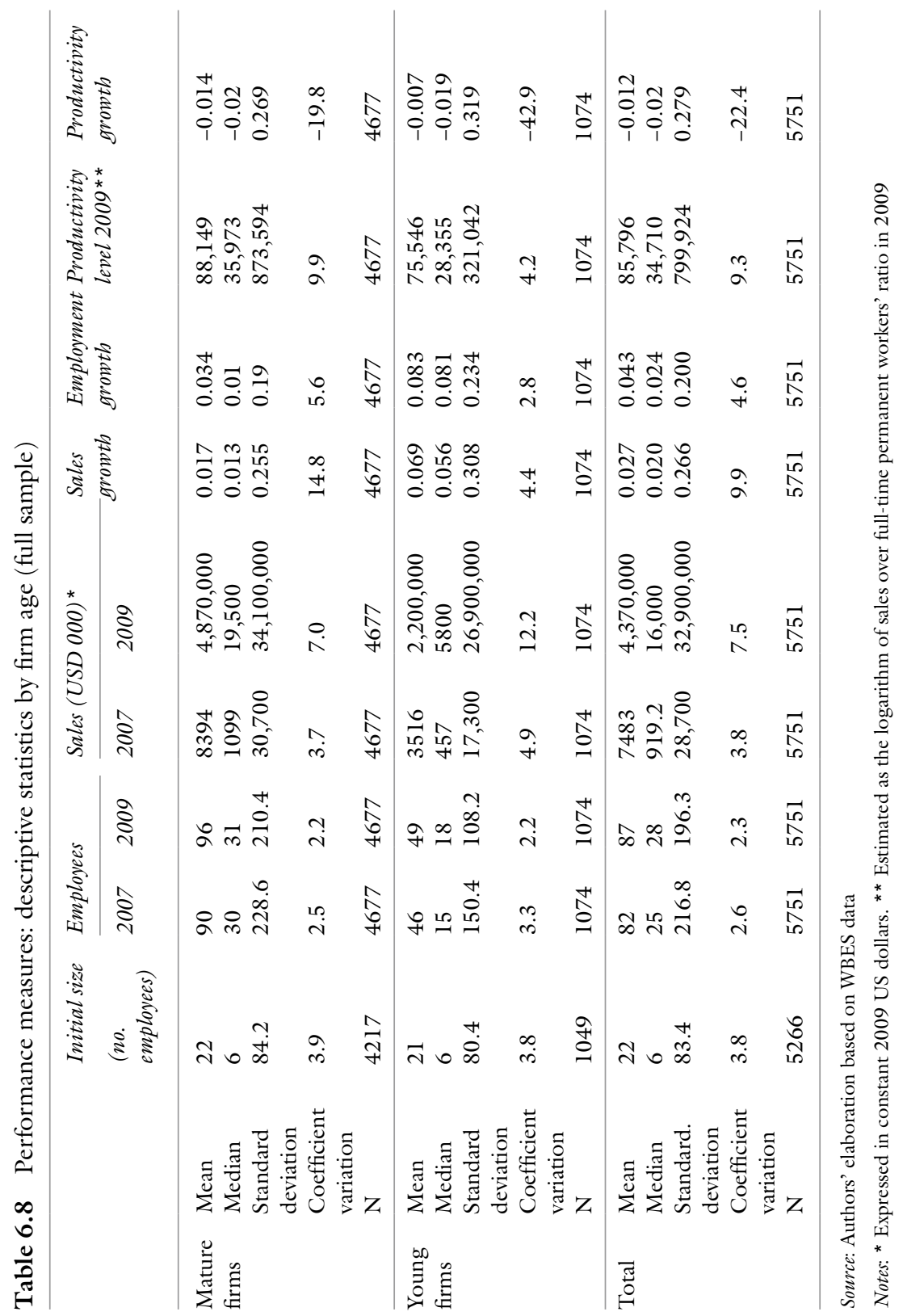




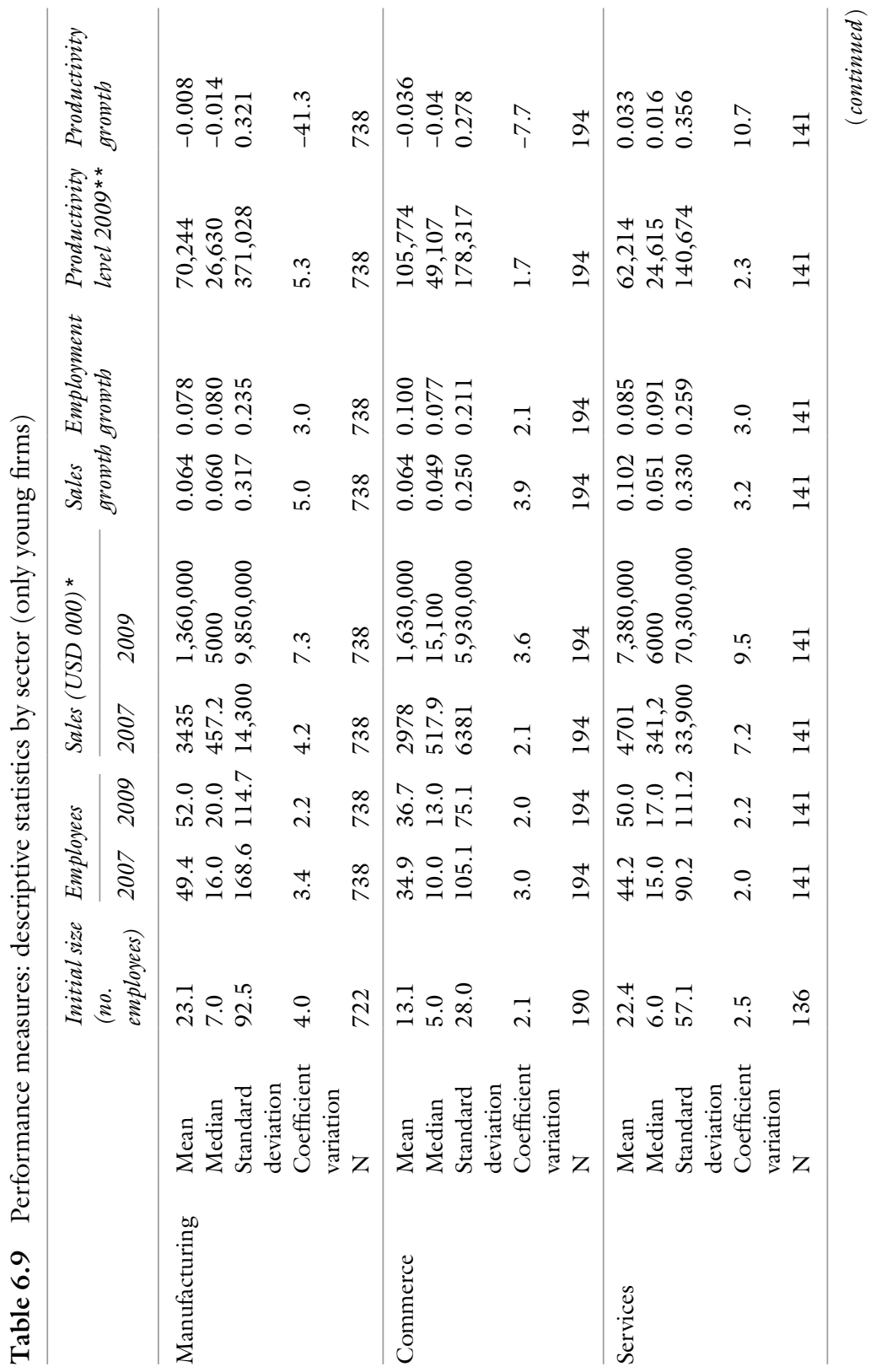




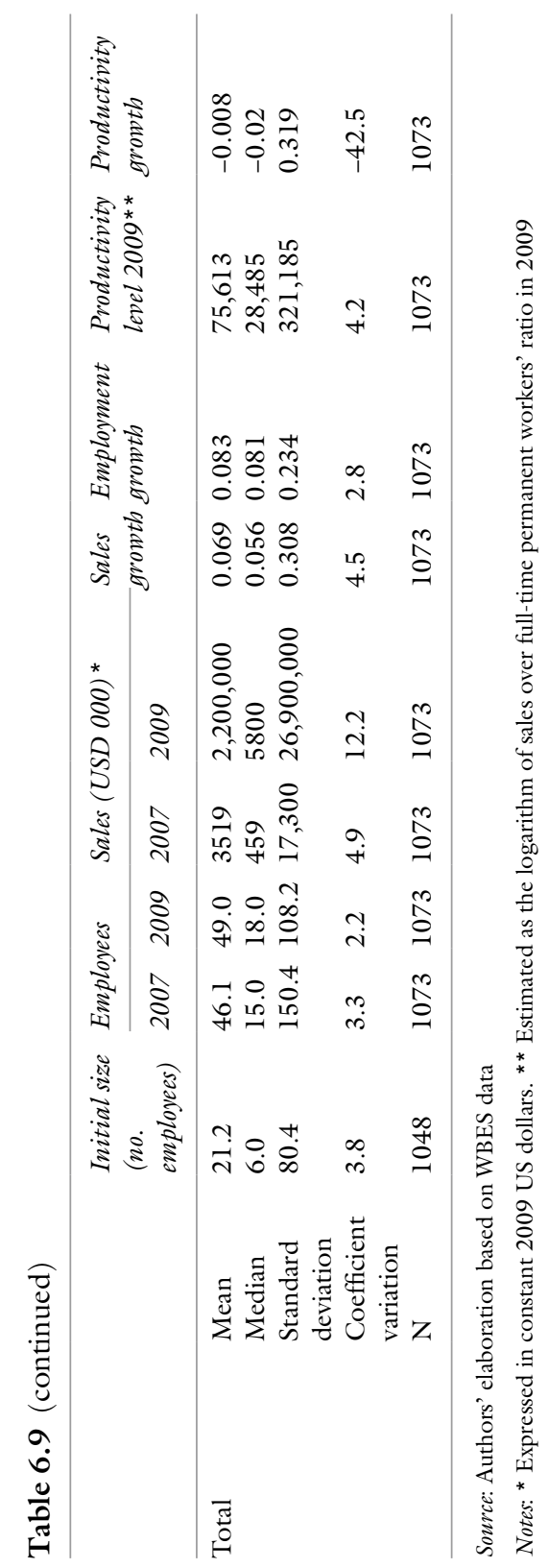


Table 6.10 Performance measures: descriptive statistics by country (only young firms)

\begin{tabular}{|c|c|c|c|c|c|c|}
\hline Country & Variable & Mean & Median & $\begin{array}{l}\text { Standard } \\
\text { deviation }\end{array}$ & $\begin{array}{l}\text { Coefficient } \\
\text { variation }\end{array}$ & $N$ \\
\hline \multirow[t]{9}{*}{ Argentina } & $\begin{array}{l}\text { Initial size (no. of } \\
\text { employees) }\end{array}$ & 31.8 & 11.0 & 69.0 & 2.2 & 60 \\
\hline & Employees 2007 & 62.3 & 25.0 & 103.0 & 1.7 & 63 \\
\hline & Employees 2009 & 63.1 & 20.0 & 102.4 & 1.7 & 63 \\
\hline & $\begin{array}{l}\text { Sales } 2007 \text { (USD } \\
000)^{*}\end{array}$ & 8639 & 1235 & 23,500 & 2.7 & 63 \\
\hline & $\begin{array}{l}\text { Sales } 2009 \text { (USD } \\
000)\end{array}$ & 30,200 & 5880 & 69,200 & 2.3 & 63 \\
\hline & Sales growth & 0.011 & 0.01 & 0.314 & 29.4 & 63 \\
\hline & $\begin{array}{l}\text { Employment } \\
\text { growth }\end{array}$ & 0.024 & 0.029 & 0.197 & 8.2 & 63 \\
\hline & $\begin{array}{l}\text { Productivity level } \\
2009^{* *}\end{array}$ & 106,364 & 57,757 & 113,084 & 1.1 & 63 \\
\hline & $\begin{array}{l}\text { Productivity } \\
\text { growth }\end{array}$ & -0.007 & -0.044 & 0.304 & -41.1 & 63 \\
\hline \multirow[t]{9}{*}{ Brazil } & $\begin{array}{l}\text { Initial size (no. of } \\
\text { employees) }\end{array}$ & 20 & 7 & 73 & 3.7 & 242 \\
\hline & Employees 2007 & 42 & 16 & 104 & 2.4 & 245 \\
\hline & Employees 2009 & 32 & 12 & 84 & 2.6 & 245 \\
\hline & $\begin{array}{l}\text { Sales } 2007 \text { (USD } \\
000)^{*}\end{array}$ & 2098 & 276 & 8158 & 3.9 & 245 \\
\hline & $\begin{array}{l}\text { Sales } 2009 \text { (USD } \\
000)\end{array}$ & 4373 & 700 & 16,000 & 3.6 & 245 \\
\hline & Sales growth & 0.110 & 0.109 & 0.416 & 3.8 & 245 \\
\hline & $\begin{array}{l}\text { Employment } \\
\text { growth }\end{array}$ & 0.163 & 0.167 & 0.277 & 1.7 & 245 \\
\hline & $\begin{array}{l}\text { Productivity level } \\
2009^{* *}\end{array}$ & 65,879 & 20,051 & 222,574 & 3.4 & 245 \\
\hline & $\begin{array}{l}\text { Productivity } \\
\text { growth }\end{array}$ & -0.034 & -0.04 & 0.442 & -12.8 & 245 \\
\hline
\end{tabular}


194 H. KANTIS ET AL.

Table 6.10 (continued)

\begin{tabular}{|c|c|c|c|c|c|c|}
\hline Country & Variable & Mean & Median & $\begin{array}{l}\text { Standard } \\
\text { deviation }\end{array}$ & $\begin{array}{l}\text { Coefficient } \\
\text { variation }\end{array}$ & $N$ \\
\hline \multirow[t]{9}{*}{ Chile } & $\begin{array}{l}\text { Initial size (no. } \\
\text { of employees) }\end{array}$ & 24.8 & 12.0 & 27.7 & 1.1 & 50 \\
\hline & Employees 2007 & 58.9 & 30.0 & 95.2 & 1.6 & 51 \\
\hline & Employees 2009 & 55.0 & 30.0 & 77.6 & 1.4 & 51 \\
\hline & $\begin{array}{l}\text { Sales } 2007 \text { (USD } \\
000)^{*}\end{array}$ & 3928 & 1839 & 5304 & 1.4 & 51 \\
\hline & $\begin{array}{l}\text { Sales } 2009 \text { (USD } \\
000)\end{array}$ & $2,250,000$ & $1,350,000$ & $2,960,000$ & 1.3 & 51 \\
\hline & Sales growth & 0.073 & 0.046 & 0.216 & 3 & 51 \\
\hline & $\begin{array}{l}\text { Employment } \\
\text { growth }\end{array}$ & 0.048 & 0.045 & 0.201 & 4.2 & 51 \\
\hline & $\begin{array}{l}\text { Productivity } \\
\text { level } 2009^{* *}\end{array}$ & 96,949 & 48,983 & 161,911 & 1.7 & 51 \\
\hline & $\begin{array}{l}\text { Productivity } \\
\text { growth }\end{array}$ & 0.031 & 0.019 & 0.202 & 6.5 & 51 \\
\hline \multirow[t]{9}{*}{ Colombia } & $\begin{array}{l}\text { Initial size (no. } \\
\text { of employees) }\end{array}$ & 16.9 & 5.0 & 48.7 & 2.9 & 154 \\
\hline & Employees 2007 & 35.0 & 14.5 & 73.6 & 2.1 & 158 \\
\hline & Employees 2009 & 36.4 & 12.0 & 79.2 & 2.2 & 158 \\
\hline & $\begin{array}{l}\text { Sales } 2007 \text { (USD } \\
000)^{*}\end{array}$ & 6063 & 402 & 38,800 & 6.4 & 158 \\
\hline & $\begin{array}{l}\text { Sales } 2009 \text { (USD } \\
000)\end{array}$ & $9,320,000$ & 890,000 & $66,900,000$ & 7.2 & 158 \\
\hline & Sales growth & 0.041 & 0.054 & 0.312 & 7.6 & 158 \\
\hline & $\begin{array}{l}\text { Employment } \\
\text { growth }\end{array}$ & 0.045 & 0.054 & 0.248 & 5.5 & 158 \\
\hline & $\begin{array}{l}\text { Productivity } \\
\text { level 2009** }\end{array}$ & 49,870 & 28,675 & 79,859 & 1.6 & 158 \\
\hline & $\begin{array}{l}\text { Productivity } \\
\text { growth }\end{array}$ & -0.009 & -0.028 & 0.314 & -35.3 & 158 \\
\hline
\end{tabular}


Table 6.10 (continued)

\begin{tabular}{|c|c|c|c|c|c|c|}
\hline Country & Variable & Mean & Median & $\begin{array}{l}\text { Standard } \\
\text { deviation }\end{array}$ & $\begin{array}{l}\text { Coefficient } \\
\text { variation }\end{array}$ & $N$ \\
\hline \multirow[t]{9}{*}{ Costa Rica } & $\begin{array}{l}\text { Initial size (no. } \\
\text { of employees) }\end{array}$ & 18.0 & 6.0 & 27.8 & 1.5 & 42 \\
\hline & Employees 2007 & 62.0 & 21.5 & 111.3 & 1.8 & 42 \\
\hline & Employees 2009 & 59.0 & 21.0 & 108.7 & 1.8 & 42 \\
\hline & $\begin{array}{l}\text { Sales } 2007 \\
(\text { USD 000)* }\end{array}$ & 3018 & 799 & 6304 & 2.1 & 42 \\
\hline & $\begin{array}{l}\text { Sales } 2009 \\
\text { (USD 000) }\end{array}$ & $1,810,000$ & 400,000 & $3,670,000$ & 2 & 42 \\
\hline & Sales growth & -0.03 & -0.059 & 0.212 & -7.1 & 42 \\
\hline & $\begin{array}{l}\text { Employment } \\
\text { growth }\end{array}$ & 0.049 & 0.011 & 0.203 & 4.1 & 42 \\
\hline & $\begin{array}{l}\text { Productivity } \\
\text { level } 2009^{* *}\end{array}$ & 57,551 & 37,768 & 86,848 & 1.5 & 42 \\
\hline & $\begin{array}{l}\text { Productivity } \\
\text { growth }\end{array}$ & -0.075 & -0.097 & 0.234 & -3.1 & 42 \\
\hline \multirow[t]{9}{*}{ Ecuador } & $\begin{array}{l}\text { Initial size (no. } \\
\text { of employees) }\end{array}$ & 10.3 & 6.5 & 13.8 & 1.3 & 44 \\
\hline & Employees 2007 & 31.7 & 14.0 & 50.9 & 1.6 & 46 \\
\hline & Employees 2009 & 29.7 & 12.5 & 49.7 & 1.7 & 46 \\
\hline & $\begin{array}{l}\text { Sales } 2007 \\
(\text { USD 000)* }\end{array}$ & 2674 & 581 & 6507 & 2.4 & 46 \\
\hline & $\begin{array}{l}\text { Sales } 2009 \\
\text { (USD 000) }\end{array}$ & 2693 & 640 & 6454 & 2.4 & 46 \\
\hline & Sales growth & 0.098 & 0.047 & 0.253 & 2.6 & 46 \\
\hline & $\begin{array}{l}\text { Employment } \\
\text { growth }\end{array}$ & 0.078 & 0.063 & 0.191 & 2.4 & 46 \\
\hline & $\begin{array}{l}\text { Productivity } \\
\text { level } 2009^{* *}\end{array}$ & 90,228 & 50,455 & 96,157 & 1.1 & 46 \\
\hline & $\begin{array}{l}\text { Productivity } \\
\text { growth }\end{array}$ & 0.027 & 0.035 & 0.276 & 10.4 & 46 \\
\hline
\end{tabular}


Table 6.10 (continued)

\begin{tabular}{|c|c|c|c|c|c|c|}
\hline Country & Variable & Mean & Median & $\begin{array}{l}\text { Standard } \\
\text { deviation }\end{array}$ & $\begin{array}{l}\text { Coefficient } \\
\text { variation }\end{array}$ & $N$ \\
\hline \multirow[t]{9}{*}{ Guatemala } & $\begin{array}{l}\text { Initial size (no. } \\
\text { of employees) }\end{array}$ & 24.6 & 6.0 & 52.2 & 2.1 & 35 \\
\hline & Employees 2007 & 62.4 & 17.0 & 116.6 & 1.9 & 36 \\
\hline & Employees 2009 & 76.4 & 12.5 & 206.7 & 2.7 & 36 \\
\hline & $\begin{array}{l}\text { Sales } 2007 \\
(\text { USD 000)* }\end{array}$ & 1943 & 212 & 4053 & 2.1 & 36 \\
\hline & $\begin{array}{l}\text { Sales } 2009 \\
\text { (USD 000) }\end{array}$ & 14,600 & 1744 & 26,600 & 1.8 & 36 \\
\hline & Sales growth & 0.028 & -0.003 & 0.176 & 6.3 & 36 \\
\hline & $\begin{array}{l}\text { Employment } \\
\text { growth }\end{array}$ & 0.022 & 0.000 & 0.224 & 10.2 & 36 \\
\hline & $\begin{array}{l}\text { Productivity } \\
\text { level } 2009^{* *}\end{array}$ & 25,587 & 18,379 & 32,556 & 1.3 & 36 \\
\hline & $\begin{array}{l}\text { Productivity } \\
\text { growth }\end{array}$ & 0.009 & -0.014 & 0.242 & 27.7 & 36 \\
\hline \multirow[t]{9}{*}{ Mexico } & $\begin{array}{l}\text { Initial size (no. } \\
\text { of employees) }\end{array}$ & 15.8 & 6.0 & 29.5 & 1.9 & 164 \\
\hline & Employees 2007 & 41.7 & 14.0 & 84.9 & 2 & 168 \\
\hline & Employees 2009 & 60.8 & 13.0 & 315.4 & 5.2 & 168 \\
\hline & $\begin{array}{l}\text { Sales } 2007 \\
(\text { USD 000)* }\end{array}$ & 2375 & 258 & 8468 & 3.6 & 168 \\
\hline & $\begin{array}{l}\text { Sales } 2009 \\
\text { (USD 000) }\end{array}$ & 37,400 & 4000 & 118,000 & 3.2 & 168 \\
\hline & Sales growth & 0.053 & 0.037 & 0.257 & 4.9 & 168 \\
\hline & $\begin{array}{l}\text { Employment } \\
\text { growth }\end{array}$ & 0.041 & 0.000 & 0.194 & 4.7 & 168 \\
\hline & $\begin{array}{l}\text { Productivity } \\
\text { level 2009** }\end{array}$ & 42,727 & 22,200 & 93,979 & 2.2 & 168 \\
\hline & $\begin{array}{l}\text { Productivity } \\
\text { growth }\end{array}$ & 0.017 & 0.001 & 0.251 & 14.6 & 168 \\
\hline
\end{tabular}


Table 6.10 (continued)

\begin{tabular}{|c|c|c|c|c|c|c|}
\hline Country & Variable & Mean & Median & $\begin{array}{l}\text { Standard } \\
\text { deviation }\end{array}$ & $\begin{array}{l}\text { Coefficient } \\
\text { variation }\end{array}$ & $N$ \\
\hline \multirow[t]{9}{*}{ Panama } & $\begin{array}{l}\text { Initial size (no. } \\
\text { of employees) }\end{array}$ & 9.5 & 5.5 & 14.3 & 1.5 & 28 \\
\hline & Employees 2007 & 30.8 & 15.0 & 40.1 & 1.3 & 31 \\
\hline & Employees 2009 & 26.5 & 10.0 & 34.4 & 1.3 & 31 \\
\hline & $\begin{array}{l}\text { Sales } 2007 \\
(\text { USD 000)* }\end{array}$ & 4237 & 161 & 8815 & 2.1 & 31 \\
\hline & $\begin{array}{l}\text { Sales } 2009 \\
\text { (USD 000) }\end{array}$ & 14,000 & 500 & 45,100 & 3.2 & 31 \\
\hline & Sales growth & 0.118 & 0.057 & 0.306 & 2.6 & 31 \\
\hline & $\begin{array}{l}\text { Employment } \\
\text { growth }\end{array}$ & 0.100 & 0.080 & 0.124 & 1.2 & 31 \\
\hline & $\begin{array}{l}\text { Productivity } \\
\text { level } 2009^{* *}\end{array}$ & 503,186 & 17,556 & $1,672,237$ & 3.3 & 31 \\
\hline & $\begin{array}{l}\text { Productivity } \\
\text { growth }\end{array}$ & 0.029 & -0.034 & 0.346 & 12.1 & 31 \\
\hline \multirow[t]{9}{*}{ Paraguay } & $\begin{array}{l}\text { Initial size (no. } \\
\text { of employees) }\end{array}$ & 20.2 & 6.5 & 25.6 & 1.3 & 34 \\
\hline & Employees 2007 & 54.1 & 20.0 & 86.1 & 1.6 & 34 \\
\hline & Employees 2009 & 32.4 & 17.0 & 52.0 & 1.6 & 34 \\
\hline & $\begin{array}{l}\text { Sales } 2007 \\
(\text { USD 000)* }\end{array}$ & 3540 & 381 & 7355 & 2.1 & 34 \\
\hline & $\begin{array}{l}\text { Sales } 2009 \\
\text { (USD 000) }\end{array}$ & $20,000,000$ & $2,250,000$ & $38,200,000$ & 1.9 & 34 \\
\hline & Sales growth & 0.066 & 0.051 & 0.182 & 2.8 & 34 \\
\hline & $\begin{array}{l}\text { Employment } \\
\text { growth }\end{array}$ & 0.124 & 0.127 & 0.252 & 2 & 34 \\
\hline & $\begin{array}{l}\text { Productivity } \\
\text { level } 2009^{* *}\end{array}$ & 69,941 & 23,905 & 105,981 & 1.5 & 34 \\
\hline & $\begin{array}{l}\text { Productivity } \\
\text { growth }\end{array}$ & -0.064 & -0.041 & 0.250 & -3.9 & 34 \\
\hline
\end{tabular}


198 H. KANTIS ET AL.

Table 6.10 (continued)

\begin{tabular}{|c|c|c|c|c|c|c|}
\hline Country & Variable & Mean & Median & $\begin{array}{l}\text { Standard } \\
\text { deviation }\end{array}$ & $\begin{array}{l}\text { Coefficient } \\
\text { variation }\end{array}$ & $N$ \\
\hline \multirow[t]{9}{*}{ Peru } & $\begin{array}{l}\text { Initial size (no. } \\
\text { of employees) }\end{array}$ & 22.3 & 6.0 & 60.7 & 2.7 & 141 \\
\hline & Employees 2007 & 77.3 & 22.0 & 187.0 & 2.4 & 145 \\
\hline & Employees 2009 & 56.8 & 19.0 & 100.2 & 1.8 & 145 \\
\hline & $\begin{array}{l}\text { Sales } 2007 \\
(\text { USD 000)* }\end{array}$ & 3039 & 683 & 6881 & 2.3 & 145 \\
\hline & $\begin{array}{l}\text { Sales } 2009 \\
\text { (USD 000) }\end{array}$ & 11,000 & 2800 & 24,000 & 2.2 & 145 \\
\hline & Sales growth & 0.077 & 0.105 & 0.274 & 3.6 & 145 \\
\hline & $\begin{array}{l}\text { Employment } \\
\text { growth }\end{array}$ & 0.091 & 0.091 & 0.233 & 2.6 & 145 \\
\hline & $\begin{array}{l}\text { Productivity } \\
\text { level } 2009^{* *}\end{array}$ & 57,786 & 28,097 & 110,905 & 1.9 & 145 \\
\hline & $\begin{array}{l}\text { Productivity } \\
\text { growth }\end{array}$ & -0.014 & -0.002 & 0.268 & -19.4 & 145 \\
\hline \multirow[t]{9}{*}{ Uruguay } & $\begin{array}{l}\text { Initial size (no. } \\
\text { of employees) }\end{array}$ & 52.9 & 8.0 & 268.5 & 5.1 & 55 \\
\hline & Employees 2007 & 43.8 & 20.0 & 49.4 & 1.1 & 55 \\
\hline & Employees 2009 & 38.4 & 20.0 & 43.2 & 1.1 & 55 \\
\hline & $\begin{array}{l}\text { Sales } 2007 \\
(\text { USD 000)* }\end{array}$ & 2696 & 1104 & 5866 & 2.2 & 55 \\
\hline & $\begin{array}{l}\text { Sales } 2009 \\
\text { (USD 000) }\end{array}$ & 72,700 & 31,400 & 143,000 & 2 & 55 \\
\hline & Sales growth & 0.115 & 0.096 & 0.217 & 1.9 & 55 \\
\hline & $\begin{array}{l}\text { Employment } \\
\text { growth }\end{array}$ & 0.072 & 0.067 & 0.174 & 2.4 & 55 \\
\hline & $\begin{array}{l}\text { Productivity } \\
\text { level 2009** }\end{array}$ & 80,884 & 41,602 & 129,612 & 1.6 & 55 \\
\hline & $\begin{array}{l}\text { Productivity } \\
\text { growth }\end{array}$ & 0.050 & 0.044 & 0.227 & 4.5 & 55 \\
\hline
\end{tabular}


Table 6.10 (continued)

\begin{tabular}{lllllll}
\hline Country & Variable & Mean & Median & $\begin{array}{l}\text { Standard } \\
\text { deviation }\end{array}$ & \multicolumn{2}{c}{$\begin{array}{l}\text { Coefficient } \\
\text { variation }\end{array}$} \\
\hline Total & $\begin{array}{l}\text { Initial size (no. } \\
\text { of employees) }\end{array}$ & 21.2 & 6.0 & 80.4 & 3.8 & 1049 \\
& $\begin{array}{l}\text { Employees 2007 } \\
\text { Employees 2009 }\end{array}$ & 48.9 & 18.0 & 108.2 & 2.2 & 1074 \\
& $\begin{array}{l}\text { Sales 2007 } \\
\text { (USD 000)* }\end{array}$ & 3516 & 457 & 17,300 & 4.9 & 1074 \\
& $\begin{array}{l}\text { Sales 2009 } \\
\text { (USD 000) }\end{array}$ & $2,200,000$ & 5800 & $26,900,000$ & 12.2 & 1074 \\
& $\begin{array}{l}\text { Sales growth } \\
\text { Employment }\end{array}$ & 0.069 & 0.056 & 0.308 & 4.4 & 1074 \\
& 0.083 & 0.081 & 0.234 & 2.8 & 1074 \\
$\begin{array}{l}\text { growth } \\
\text { Productivity } \\
\text { level 2009** }\end{array}$ & 75,546 & 28,355 & 321,042 & 4.2 & 1074 \\
& $\begin{array}{l}\text { Productivity } \\
\text { growth }\end{array}$ & -0.007 & -0.019 & 0.319 & -42.9 & 1074 \\
\hline
\end{tabular}

Source: Authors' elaboration based on WBES data

Notes: * Expressed in constant 2009 US dollars. ** Estimated as the logarithm of sales over full-time permanent workers' ratio in 2009 


\section{Notes}

1. Empirical evidence about high-growth firms is still inconclusive and presents a number of methodological and statistical limitations, as recently highlighted by Nightingale and Coad (2013).

2. For some descriptive analyses, we also include a control group of mature firms (i.e. firms older than ten years).

3. All sales values are expressed in constant 2009 US dollars.

4. To account for the possible differential effect of certain variables on firm performance according to its dynamics, we run some auxiliary quartile regressions. Where appropriate, we include the results from these estimations in endnotes.

5. In addition, the models omit any firms that did not respond to innovation and/or human resources questions and therefore have missing information for these variables.

6. We recognize the possibility of endogeneity, which could bias our estimations. Unfortunately, in the case of young firms, there are not enough observations to build a panel, which is why we are forced to focus on crosssectional data. Additionally, data limitations would reduce the number of valid instruments that could be used to control for potential endogeneity.

7. This situation would affect mean analyses since they are sensitive to the presence of extreme values.

8. This figure refers to the proportion of young firms of the full sample (see Table 6.8 in the Appendix). The proportion of young firms in the total sample is higher in Panama, at $27 \%$, and in Peru, at $25 \%$. On the contrary, Chile and Argentina have the lowest proportion of young firms (10\%).

9. In Argentina, $38 \%$ of young firms are in knowledge-based sectors vs $31 \%$ mature firms; Chile, 33 vs $25 \%$; Colombia, 23 vs $19 \%$; Ecuador, 9 vs $6 \%$; Panama, 13 vs $6 \%$; Paraguay, 12 vs $7 \%$; Peru, 25 vs $17 \%$.

10. The presence of female entrepreneurs is lower in services than in manufacturing activities ( 38 vs $26 \%$ ). In Paraguay and Colombia, the presence of female entrepreneurs or managers is higher than in the remaining countries, reaching $50 \%$. On the contrary, in Chile, the percentage of women owners or managers is just above 20.

11. Unfortunately, the WBES do not ask about previous entrepreneurial experience, so it is not possible to track serial or habitual entrepreneurs.

12. According to the WBES definition, permanent, full-time employees are paid employees that are contracted for a term of one or more fiscal years and/or have a guaranteed renewal of their employment contract and that work for eight or more hours per day.

13. See more on the size distribution of firms among countries in the Appendix.

14. In Costa Rica, $27 \%$ are young active exporters; in Peru, 19\%; and in Argentina, $17 \%$. 
15. "Born globals" are companies that conduct international business at or near the time of the firm's founding.

16. Innovation data is only available for manufacturing firms. The WBES of Brazil does not include the innovation section.

17. The initial startup phase refers to the number of full-time workers employed when the firm first started operations; the median is six full-time workers, but with a high degree of dispersion.

18. One key feature to note here is that firm heterogeneity, measured by the coefficient of variation, tends to diminish with time, although it is still important. The coefficient of variation of employment size is 3.78 at startup, 3.26 in 2007 , and 2.21 in 2009.

19. We obtain the same results when we compare employment growth between young and mature firms ( 8 and $1 \%$, respectively).

20. The annual average growth rate was particularly fast in Brazil $(36 \%)$, Colombia (21\%), and Peru (26\%).

21. Looking at sales growth, the general overview is similar both in terms of average growth and the existence of a relevant proportion that grew their sales at an annual rate higher than $20 \%$ on average $(25 \%)$.

22. Engineering-intensive manufacturing includes metal-mechanic, automotive industry, electrical, and electronic equipment. Technological services include, for example, software development.

23. Only manufacturing firms are included in the models because data about innovation and capabilities is only available for this sector. The innovation module was not included in the 2009 survey wave in Brazil, which is, therefore, excluded from the econometric analysis.

24. As in the previous section, we define high-growth firms as those young firms that are SMEs (i.e. ten or more employees in 2009) and experienced high-growth rates in sales between 2007 and 2009. We acknowledge that this estimator could be biased because of the potential endogeneity between the growth and productivity variables.

25. In addition, we view these results cautiously since we are only measuring labor productivity, which could be less influenced by such strategies.

26. In fact, it could be the case that those firms with poorer performance are those more prone to report external obstacles, precisely because of their situation. This would be a sign of potential bias due to endogeneity.

27. To check statistically the difference between the two sets of regressors, we run a test on the difference between the two joint sets of coefficients, finding it significantly different from 0 . Then, we test the difference between the most relevant single coefficients in the two regressions. In this case, the results show that the coefficients for experience, technical assistance, and gender are statistically different in the two equations, but we cannot reject the null hypothesis of zero difference for financial constraint and regulation. 
28. We also run the same regressions on a sample of older firms and the results are quite similar. The only change worth mentioning is that managers' previous work experience affects productivity and sales growth in young firms, while for older firms the signs are the opposite. This result makes sense since young firms' knowledge base and social capital (networks)critical issues when it comes to firm performance-would depend heavily on entrepreneurs' previous industry experience. In older firms, formal and professional management and operation structures would already be in place, so the relationship between managers' industry experience and performance would be less clear.

29. Some institutions, such as Endeavor or Enablis, are examples of such programs. The Chilean government's new entrepreneurship policy includes a mentoring program. For earlier stages, business accelerators, such as Wayra or Nextplabs, both with operations at the regional level, should also be mentioned.

30. To some extent, the instrument Proyectos de Innovación de Amplia Cobertura implemented by the National Agency of Research and Innovation in Uruguay could be considered an example of this type of idea (see www.anii.org.uy). Other initiatives in this vein include the ANR Recursos Humanos Altamente Calificados executed by the National Agency of Science and Technology in Argentina (see http://www.mincyt. gob.ar).

\section{REFERENCES}

Acs, Z.J., and D.B. Audretsch. 2005. Entrepreneurship, Innovation, and Technological Change. Hanover, MA: Now Publishers.

Acs, Z.J., S. Desai, and J. Hessels. 2008. Entrepreneurship, Economic Development and Institutions. Small Business Economics 31(3): 219-234.

Acs, Z.J., L. Szerb, and E. Autio. 2014. Global Entrepreneurship and Development Index 2014. Washington, DC: Global Entrepreneurship and Development Institute. Available at http://thegedi.org/global-entrepreneurship-anddevelopment-index/.

Álvarez, S., and L. Busenitz. 2001. The Entrepreneurship of Resource-Based Theory. Journal of Management 27(6): 755-775.

Audretsch, D., and M. Keilbach. 2007. The Theory of Knowledge Spillover Entrepreneurship. Journal of Management Studies 44(7): 1242-1254.

Ayyagari, M., A. Demirguc-Kunt, and V. Maksimovic. 2011. Small vs. Young Firms Across the World: Contribution to Employment, Job Creation, and Growth. Policy Research Working Paper 5631. Washington, DC: The World Bank.

Baum, J.R., E.A. Locke, and K.G. Smith. 2001. A Multidimensional Model of Venture Growth. Academy of Management Journal 44(2): 292-303. 
Bridge, S., K. O’Neill, and S. Cromie. 1998. Understanding Enterprise, Entrepreneurship and Small Business. London: Palgrave Macmillan.

Brüderl, J., P. Preisendörfer, and R. Zieger. 1992. Survival Chances of Newly Founded Business Organizations. American Sociological Review 57(2): 227-242.

CAF. 2013. Emprendimientos en América Latina. Desde la subsistencia hacia la transformación productiva. Caracas: CAF Development Bank of Latin America $(\mathrm{CAF})$.

Capelleras, J.L., and H. Kantis. 2009. Nuevas empresas en América Latina: factores que favorecen su rápido crecimiento. Barcelona: University of Barcelona, Office of Publications.

Chan, S., and M. Foster. 2001. Strategy Formulation in Small Business, the Hong Kong Experience. International Small Business Journal 19(3): 56-71.

Chrisman, J., A. Bauerschmidt, and C. Hofer. 1998. The Determinants of New Venture Performance: An Extended Model. Entrepreneurship Theory and Practice 23(Fall): 5-29.

Colombo, M., and L. Grilli. 2005. Founder's Human Capital and the Growth of new Technology-Based Firms: A Competence-Based View. Research Policy 34(6): 795-816.

Cooper, A., F.J. Gimeno-Gascon, and C. Woo. 1994. Initial Human and Financial Capital as Predictors of New Venture Performance. Journal of Business Venturing 9(5): 371-396.

Davidsson, P., F. Delmar, and J. Wiklund. 2006. Entrepreneurship and the Growth of Firms. Cheltenham, UK: Edward Elgar Publishing.

Federico, J., R. Rabetino, and H. Kantis. 2012. Comparing Young SMEs' Growth Determinants Across Regions. Journal of Small Business and Enterprise Development 19(4): 575-588.

Garnsey, E. 1998. A Theory of the Early Growth of the Firm. Industrial and Corporate Change 7(3): 523-556.

Gilbert, B., P. McDougall, and D. Audretsch. 2006. New Venture Growth: A Review and Extension. Journal of Management 32(6): 926-950.

Gompers, P.A., and J. Lerner. 2004. The Venture Capital Cycle. Cambridge, MA: MIT Press.

Grant, R. 1991. The Resource-Based Theory of Competitive Advantage: Implications for Strategy Formulation. California Management Review 33(3): 114-135.

Greiner, L.E. 1972. Evolution and Revolution as Organizations Grow. Harvard Business Review 50(4): 37-46.

Henrekson, M., and D. Johansson. 2010. Gazelles as Job Creators: A Survey and Interpretation of the Evidence. Small Business Economics 35(2): 227-244.

Kantis, H. 2010. Aportes para el diseño de políticas integrales de desarrollo emprendedor en América Latina. Washington, DC: Inter-American Development Bank (IDB). 
Kantis, H. (ed.). 2014. ¿Emprendimientos dinámicos en América del Sur?: la clave es el (eco)sistema. Montevideo, Uruguay: Mercosur Economic Research Network.

Kantis, H., P. Angelelli, and V. Moori Koenig. 2005. Developing Entrepreneurship: Latin America and World Wide Experience. Washington, DC: IDB.

Kantis, H., J. Federico, and C. Menéndez. 2012. Políticas de fomento al emprendimiento dinámico en América Latina: tendencias y desafíos. Working paper. Caracas: CAF.

Kantis, H., M. Ishida, and M. Komori. 2002. Entrepreneurship in Emerging Economies: The Creation and Development of New Firms in Latin America and East Asia. Washington, DC: IDB.

Lederman, D., J. Messina, S. Pienknagura, and J. Rigolini. 2014. Latin American Entrepreneurs: Many Firms but Little Innovation. Washington, DC: The World Bank.

Lee, C., K. Lee, and J.M. Pennings. 2001. Internal Capabilities, External Networks, and Performance: A Study on Technology-Based Ventures. Strategic Management Journal 22(6/7): 615-640.

Levie, J., and B. Lichtenstein. 2010. A Terminal Assessment of Stages Theory: Introducing a Dynamic States Approach to Entrepreneurship. Entrepreneurship Theory and Practice 34(2): 317-350.

Mason, C. 1998. El financiamiento y las pequeñas y medianas empresas. In Desarrollo y gestión de PYMEs: Aportes para un debate necesario, H. Kantis (ed.). Buenos Aires, Argentina: National University of General Sarmiento (known by its Spanish acronym UNGS).

Nightingale, P., and A. Coad. 2013. Muppets and Gazelles: Political and Methodological Biases in Entrepreneurship Research. Working Paper Series 2013-03. Brighton, UK: Science Policy Research Unit or the University of Sussex (SPRU).

Pagés, C. (ed.). 2010. The Age of Productivity: Transforming Economies from the Bottom Up. London, UK: Palgrave Macmillan.

Pellegrino, G., M. Piva, and M. Vivarelli. 2012. Young Firms and Innovation: A Microeconometric Analysis. Structural Change and Economic Dynamics 23(4): 329-340.

Quince, T., and H. Whittaker. 2002. Close Encounters: Evidence of the Potential Benefits of Proximity to Local Industrial Clusters. Cambridge, UK: ESRC Centre for Business Research, University of Cambridge.

Schneider, C., and R. Veugelers. 2010. On Young Highly Innovative Companies: Why They Matter and How (Not) to Policy Support Them. Industrial and Corporate Change 19(4): 969-1007.

Shane, S. 2000. Prior Knowledge and the Discovery of Entrepreneurial Opportunities. Organization Science 11(4): 448-469.

Stinchcombe, A. 1965. Social Structure and Organizations. In Handbook of Organizations, ed. J. March. Chicago, IL: Rand McNally.

Storey, D. 1994. Understanding the Small Business Sector. London, UK: Routledge. 
Stuart, R., and P. Abetti. 1990. Impact of Entrepreneurial and Management Experience on Early Performance. Journal of Business Venturing 5(3): $151-162$.

Ucbasaran, D., P. Westhead, and M. Wright. 2008. Opportunity Identification and Pursuit: Does an entrepreneur's Human Capital Matter. Small Business Economics 30(2): 153-173.

World Bank. 2010. The World Bank Annual Report 2010. Washington, DC: The World Bank Group.

World Bank. 2013. World Bank Enterprise Surveys (WBES). Indicator Descriptions. Washington, DC: The World Bank Group.

World Bank. 2014. Innovating in the Manufacturing Sector in Latin America and the Caribbean. Latin America and the Caribbean Series Note No. 9. Washington, DC: The World Bank Group.

(c) (i) (\$) $\odot$ Except where otherwise noted, this work is licensed under a Creative (c) ${ }_{\mathrm{Br}} \mathrm{Nc}$ No Commons Attribution-NonCommercial-NoDerivatives 3.0 IGO License. To view a copy of this license, visit https://creativecommons.org/licenses/ by-nc-nd/3.0/igo/ 